Article

\title{
A Study on the Job Retention Intention of Nurses Based on Social Support in the COVID-19 Situation
}

\author{
Young-Jae Kim ${ }^{1}$, So-Young Lee ${ }^{2}$ and Jeong-Hyung Cho ${ }^{1, *}$ \\ 1 Department of Physical Education of Chung-Ang University, Seoul 06974, Korea; yjkim@cau.ac.kr \\ 2 Department of Nursing of Jungwon University, Chungbuk 28024, Korea; soyoung.lee@jwu.ac.kr \\ * Correspondence: cheer1007@naver.com; Tel.: +82-2-820-5386
}

Received: 5 July 2020; Accepted: 30 August 2020; Published: 4 September 2020

\begin{abstract}
This study investigated how social support influences the job engagement and job retention intention of nurses struggling in the continuing scenes of the COVID-19 pandemic. To this end, 382 nurses were the participants, data from 377 of whom were analyzed in total, with the following results. First, it showed that nurses' job engagement and job retention intention were high, depending on their age and work experience. Second, in terms of the factors related to COVID-19, the group with experience in nursing patients infected with COVID-19 and nurses working in COVID-19 divisions had low job retention intention. Lastly, it appeared that there were differences in job engagement and job retention intention depending on the category and type of social support. These results suggest that social support should be provided strategically to ensure nurses' job retention.
\end{abstract}

Keywords: COVID-19; nurse; job engagement; social support

\section{Introduction}

Since the first outbreak of COVID-19 in December 2019 [1], there are now (7 May 2020) approximately 3,871,312 infected and 272,856 deaths as a result of the COVID-19 pandemic [2]. The rapid spread of COVID-19 around the world has caused serious damage to each nation, including fatal risks, unemployment, and deteriorating work-life balance [3-5]. Accordingly, a state of emergency was declared worldwide because of COVID-19, and efforts are being exerted to overcome the current situation [6]. This includes nurses taking care of COVID-19 patients at the scenes of COVID-19 infections, where they have to wear protective equipment for many hours, leaving marks on their faces [7]. However, as COVID-19 has been ongoing for a long time, nurses are facing hardships in carrying out their jobs [8,9]. In every country, nurses are being praised for their efforts, and countless encouraging messages are relayed to medical workers through mass media. For example, Banksy, an anonymous England-based street artist, sent a painting to Southampton General Hospital that memorialized nurses as children's heroes [10]. In addition, people are spreading encouraging dance challenge videos with the theme of "support for the nurses" through social networking services' platforms [11]. These efforts recognize that nurses are the most directly exposed to COVID-19 and that their work has increased dramatically during the pandemic; in so doing, they bring greater awareness to the situation, and nurses around the world have praised these efforts [12].

This social support (i.e., encouragement sent to nurses) is possible because many people can relate to the sacrifices and service of the nurses in the COVID-19 pandemic despite the risks. Social support has a positive effect on subjects' mental health; in particular, it influences job-related stress reduction and can even enhance self-esteem [13]. In addition, as technology develops, social knowledge is being created through the means of social networks [14].

In a study by Lee and Yoon [15], it was found that nurses who received social support had reduced depression and high self-resilience. Furthermore, social support reduces nurses' emotional labor and 
burnout [16]. Since the COVID-19 situation absolutely requires the staffing of nurses, it is imperative to study the effectiveness of nurses' current social support. Social support is conceptually defined as providing individuals with resources in either tangible or intangible forms, which are typically divided into the categories of emotional, instrumental, or informational support, and appraisal [17]. Additionally, social support is characterized by mutuality, that is, an exchange in resources between individuals or between an individual and a group. Sullivan [18] stated that people want to have positive relationships with others and feel accepted, so efforts are made for social interaction. Social support appears differently as individuals face more difficult situations. Krause [19] stated that in this sense, social support could be harmful, although most cases of social support are considered positive. For example, social support can have positive effects such as reducing stress and improving self-esteem, but alcohol consumption and stress may increase [20,21]. Precedent studies conducted on social support show that it was used as a measure of social resources to control the stress that results from the working environment [22,23]. Munro's research [24], which targeted 60 Australian nurses, showed that social support has a negative relationship with initial stress. Moreover, Lee Young Mi [15] stated that nurses' social support appears differently depending on general characteristics, and job satisfaction is higher when social support is recognized. Recent studies show that social workers' turnover is positively affected by social support [25], and a study of nurses said that social support helps them cope with the working environment and thrive [13].

Therefore, it is necessary to investigate how social support influences job retention for nurses who are managing duties that are more difficult than usual in the pandemic situation. However, according to research results related to nurses in the context of the COVID-19 epidemic, the nurses' working environment is dangerous and more exhausting than usual [26-28]. A study by Maben and Bridges [29] suggested that nurses need psychological and mental health support. In addition, only studies about the high job stress of nurses in pandemic outbreak situations and turnover intention are in progress $[30,31]$, and there is insufficient practical research into how social support recognized by nurses is connected to job retention. In response, this study aims to investigate how social support affects job engagement and how the job retention intention of nurses is affected by social support in the continuing COVID-19 situation.

\section{Materials and Methods}

\subsection{Participants}

The sample of this study included nurses who had a national nursing certificate. In addition, only nurses currently on duty were allowed to participate; this was assured through screening questions administered before they participated in the questionnaire. Data were collected from 11-24 May 2020, when confirmed cases of COVID-19 were $<10$ patients a day, but then suddenly started increasing to $20-30$ patients. The size of the samples used in the study was calculated using the $G^{*}$ power 3.0 program (Heinrich-Heine-Universität Düsseldorf, Düsseldorf, Germany), and, as a result of calculating by applying 0.15 moderate effect size, 0.05 level of significance and 0.85 statistical power, at least 314 participants were required. In this study, participants who were voluntarily willing to participate were selected, and 382 participants joined in total. Among them, the data of 377 participants were used. Responses that had the same number of answers and those in which the respondent had the highest job rank but lowest earned income were excluded from the data. For the survey, a Google online questionnaire was made and distributed to the participants via email out of consideration for COVID-19. This study was conducted with the approval of the Institutional Review Board of Chung-Ang University (1041078-202005-HRSB-124-01). 


\subsection{Measurement}

\subsubsection{Job Engagement}

To measure job engagement, this study used the tool developed by Kim [32], which was a modified translation of the Utrecht Work Engagement Scale (UWES) developed by Schaufeli and Bakker [33] accompanied by Kim's supplements. This tool consists of 17 questions in three sub-areas: energy (six questions), sacrifice (five questions), and immersion (six questions). Typical questions include "When I wake up in the morning, I want to go to work," "I can work for a long time at a time," and "I feel proud of my work." The questionnaire consisted of a five-point scale in which one point represents strongly disagree and five points indicates strongly agree. The higher score on the five-point Likert scale signifies a higher level of job engagement. In this study, Cronbach's $\alpha$ was 0.91 , and the sub-areas were 0.87 for energy, 0.84 for sacrifice, and 0.82 for immersion. The exploratory factor analysis for Job Engagement is given in Table 1.

Table 1. Results of Exploratory Factor Analysis (EFA) for Job Engagement Scale.

\begin{tabular}{|c|c|c|c|}
\hline \multirow{2}{*}{ Items } & \multicolumn{3}{|c|}{ EFA } \\
\hline & 1 & 2 & 3 \\
\hline Energy 4 & 0.835 & & \\
\hline Energy 3 & 0.808 & & \\
\hline Energy 1 & 0.800 & & \\
\hline Energy 6 & 0.706 & & \\
\hline Energy 2 & 0.696 & & \\
\hline Energy 7 & 0.583 & & \\
\hline Energy 5 & 0.565 & & \\
\hline Sacrifice 3 & & 0.870 & \\
\hline Sacrifice 4 & & 0.745 & \\
\hline Sacrifice 1 & & 0.540 & \\
\hline Sacrifice 2 & & 0.518 & \\
\hline Immersion 1 & & & 0.780 \\
\hline Immersion 2 & & & 0.712 \\
\hline Immersion 3 & & & 0.594 \\
\hline Cronbach's $\alpha$ & 0.866 & 0.842 & 0.817 \\
\hline Eigenvalue & 4.111 & 2.702 & 1.920 \\
\hline Variance $(\%)$ & 29.363 & 19.303 & 13.714 \\
\hline Variance Cumulated (\%) & 29.363 & 48.666 & 62.380 \\
\hline \multicolumn{4}{|c|}{$\mathrm{KMO}=0.835, \chi^{2}=1408.494, \mathrm{df}=66, p<0.001$} \\
\hline
\end{tabular}

\subsubsection{Job Retention Intention}

As the measurement tool for job retention intention, this study used questions from the Theory of Planned Behavior (TPB) developed by Ajzen [34] that measured behavioral intention. The Theory of Planned Behavior consists of a structure with four independent factors including attitudes about behavior, subjective norm, perceived behavioral control, and behavioral intention. In this study, only the three questions related to behavioral intention were used. Job engagement questions consisted of "I will continue my career next month," "I will continue my career after six months," and "I will continue my career after a year." The questionnaire consisted of a five-point scale with one point indicating strongly disagree and five points meaning strongly agree. The behavioral intention factor is composed of a five-point Likert scale, and in this study, the higher the score, the greater the nurse's intention to keep the job. The reliability analysis, Cronbach's $\alpha$, was found to be 0.87 . 


\subsubsection{Social Support}

This study organized questions based on the content and composition of social support in the studies of Shirey [14] and Choo [35], who studied nurses. Social support consisted of three questions in total: "experience of social support," "social support categories," and "types of social support." The questions were as follows: "Have you ever received or seen social support to nurses during COVID-19? Who did you receive social support from? What type of social support did you receive?" The social support questions are all composed of nominal measures.

\subsection{Data Analysis}

To achieve the study purpose, all the analyses for this study were performed using SPSS Ver. 25.0 (IBM, Armonk, NY, USA) after encoding and data cleaning. In order to examine socio-demographic factors, frequency analysis and descriptive analysis were conducted, and to obtain reliability and validity of the measuring instrument, Cronbach's $\alpha$ and exploratory factor analysis were carried out. Lastly, a $t$-test and one-way ANOVA were executed to investigate differences in job engagement and job retention intention depending on the independent variables (characteristics of the subjects and types of social support).

\section{Results}

Table 2 presents the characteristics of the nurses involved in this study. Females participated more than males, and females showed a higher level of job engagement and job retention intention than males as well. The group of the nurses aged 41 or over showed the highest level of job engagement and job retention intention, and married respondents showed a higher level of job engagement and job retention intention. The group of nurses working for general hospitals occupied the largest proportion of the participants, but the group of those working for health centers and communities showed a higher level of job engagement and job retention intention. The group of head nurses displayed a higher level of job engagement, and the group of charge nurses displayed a higher level of job retention intention. In relation to COVID-19-related characteristics, the nurses with experience in caring for COVID-19 patients had a higher level of job engagement.

Table 3 shows the results of nurses' job engagement. While the differences in job engagement followed by social support were not statistically significant, the group that recognized it $(M=3.392$, $\mathrm{SD}=0.639)$ showed a high result $(\mathrm{F}=2.145, p>0.05)$. In the case of the detailed differences that appeared depending on the category of support, the group that received support from family displayed the highest level of engagement $(\mathrm{M}=3.541, \mathrm{SD}=0.578)$, and the group supported by work colleagues $(\mathrm{M}=2.998, \mathrm{SD}=0.657)$ scored the lowest $(\mathrm{F}=3.463, p<0.001)$. In terms of the types of social support, social support group through the mass media $(\mathrm{M}=3.454, \mathrm{SD}=0.654)$ showed the highest job engagement $(\mathrm{F}=0.380, p>0.05)$.

Table 4 shows the differences in the job retention intention of nurses followed by social support. The job retention intention of nurses based on social support was highest for the group that could not recognize social support $(\mathrm{M}=3.952, \mathrm{SD}=1.001)$, but there was no significant difference $(\mathrm{F}=2.918$, $p>0.05)$. For the detailed differences followed by the support categories, the group that recognized national encouragement $(M=4.174, S D=0.968)$ recorded the highest scores for job retention intention, and the group that recognized encouragement by the company $(\mathrm{M}=3.577, \mathrm{SD}=0.929)$ recorded the lowest $(\mathrm{F}=2.997, p>0.05)$. Lastly, in terms of the types of social support, the group that recognized encouragement through mass media $(\mathrm{M}=4.227, \mathrm{SD}=0.972)$ had the highest job retention intention $(\mathrm{F}=3.389, p<0.05)$. 
Table 2. Demographic Characteristics and Scores by Variables $(n=377)$.

\begin{tabular}{|c|c|c|c|c|c|c|c|c|}
\hline \multirow{2}{*}{ Variable } & \multirow{2}{*}{$n$} & \multirow{2}{*}{$\%$} & \multicolumn{3}{|c|}{ Job Engagement } & \multicolumn{3}{|c|}{ Job Retention Intention } \\
\hline & & & $\mathbf{M}$ & SD & $\mathbf{F} / \mathbf{t}$ & $\mathbf{M}$ & SD & $\mathbf{F} / \mathbf{t}$ \\
\hline \multicolumn{9}{|c|}{ Gender } \\
\hline Male & 39 & 10.3 & 3.431 & 0.674 & \multirow[b]{2}{*}{0.521} & 3.803 & 0.843 & \multirow{2}{*}{0.487} \\
\hline Female & 338 & 89.7 & 3.350 & 0.667 & & 3.922 & 1.022 & \\
\hline \multicolumn{9}{|c|}{ Age (years) } \\
\hline$\leq 25$ & 18 & 4.8 & 3.511 & 0.495 & \multirow{5}{*}{$9.713^{* * *}$} & 3.648 & 0.918 & \multirow{5}{*}{$9.785^{* * *}$} \\
\hline $26-30$ & 115 & 30.5 & 3.089 & 0.699 & & 3.655 & 1.020 & \\
\hline $31-35$ & 114 & 30.2 & 3.368 & 0.630 & & 3.733 & 0.985 & \\
\hline $36-40$ & 65 & 17.2 & 3.460 & 0.602 & & 4.220 & 0.907 & \\
\hline$\geq 41$ & 65 & 17.2 & 3.672 & 0.609 & & 4.430 & 0.865 & \\
\hline \multicolumn{9}{|c|}{ Married } \\
\hline Yes & 145 & 38.5 & 3.529 & 0.677 & \multirow{2}{*}{$16.127^{* * *}$} & 4.160 & 0.943 & \multirow{2}{*}{$\begin{array}{c}15.275 \\
* * *\end{array}$} \\
\hline No & 232 & 61.5 & 3.251 & 0.617 & & 3.752 & 1.011 & \\
\hline \multicolumn{9}{|c|}{ Income (USD) } \\
\hline$\leq \$ 1500$ & 44 & 11.7 & 3.358 & 0.766 & \multirow{4}{*}{$2.797 *$} & 4.030 & 1.198 & \multirow{4}{*}{$6.514^{* * *}$} \\
\hline$\$ 1501-2500$ & 185 & 49.1 & 3.296 & 0.669 & & 3.733 & 0.984 & \\
\hline$\$ 2501-3500$ & 104 & 27.6 & 3.359 & 0.620 & & 3.948 & 0.990 & \\
\hline$>\$ 3500$ & 44 & 11.7 & 3.617 & 0.625 & & 4.439 & 0.673 & \\
\hline \multicolumn{9}{|c|}{ Type of workplace } \\
\hline Senior general hospital & 121 & 32.1 & 3.345 & 0.660 & \multirow{3}{*}{0.927} & 3.961 & 0.989 & \multirow{3}{*}{$6.621^{* * *}$} \\
\hline General hospital & 159 & 42.2 & 3.321 & 0.627 & & 3.712 & 0.974 & \\
\hline Health center and community & 97 & 25.7 & 3.436 & 0.738 & & 4.168 & 1.015 & \\
\hline \multicolumn{9}{|c|}{ Nursing position } \\
\hline General nurse & 296 & 78.5 & 3.277 & 0.660 & \multirow{3}{*}{$14.689^{* * *}$} & 3.810 & 1.012 & \multirow{3}{*}{$6.758^{* * *}$} \\
\hline Charge nurse & 56 & 14.9 & 3.525 & 0.572 & & 4.279 & 0.898 & \\
\hline Head nurse & 25 & 6.6 & 3.948 & 0.611 & & 4.253 & 0.898 & \\
\hline \multicolumn{9}{|c|}{ Nursing experience (years) } \\
\hline$<1$ & 37 & 9.8 & 3.180 & 0.791 & \multirow{5}{*}{$2.867 *$} & 3.297 & 1.102 & \\
\hline $1-3$ & 71 & 18.8 & 3.291 & 0.575 & & 3.770 & 0.767 & \\
\hline $3-5$ & 81 & 21.5 & 3.403 & 0.606 & & 3.843 & 0.897 & $9.294 * * *$ \\
\hline Between 5-10 & 103 & 27.3 & 3.283 & 0.694 & & 3.890 & 1.143 & \\
\hline$>10$ & 85 & 22.5 & 3.539 & 0.675 & & 4.380 & 0.860 & \\
\hline & & VID-1 & ursing & erience & & & & \\
\hline Yes & 44 & 11.7 & 3.478 & 0.623 & & 3.674 & 0.935 & \\
\hline No & 333 & 88.3 & 3.342 & 0.672 & 1.598 & 3.940 & 1.101 & 2.764 \\
\hline & Serv & in $\mathrm{CC}$ & D-19 re & ed divi & on & & & \\
\hline Yes & 45 & 11.9 & 3.170 & 0.797 & & 3.688 & 1.013 & \\
\hline No & 332 & 88.1 & 3.383 & 0.645 & $4.064^{*}$ & 3.939 & 1.001 & 2.480 \\
\hline Total & 377 & 100 & 3.358 & 0.667 & & 3.909 & 1.004 & \\
\hline
\end{tabular}

Table 3. Result of one-way analysis of variance about job engagement.

\begin{tabular}{|c|c|c|c|c|c|c|c|c|}
\hline Item & $\begin{array}{l}\text { Frequency } \\
\qquad(n)\end{array}$ & Average & $\begin{array}{l}\text { Standard } \\
\text { Deviation }\end{array}$ & $\begin{array}{l}\text { Mean } \\
\text { Square }\end{array}$ & $\mathbf{F}$ & Probability & $\begin{array}{l}\text { Observed } \\
\text { Power }\end{array}$ & $\begin{array}{c}\text { Post } \\
\text { Verification }\end{array}$ \\
\hline \multicolumn{9}{|c|}{ Experience of social support $(n=377)$} \\
\hline Yes & 260 & 3.392 & 0.639 & 0.954 & 2.145 & 0.144 & 0.309 & \\
\hline No & 117 & 3.283 & 0.724 & & & & & \\
\hline \multicolumn{9}{|c|}{ Social support categories $(n=260)$} \\
\hline Family ${ }^{a}$ & 93 & 3.541 & 0.578 & & & & & \\
\hline Friend ${ }^{b}$ & 50 & 3.336 & 0.674 & & & & & \\
\hline Colleague $^{c}$ & 20 & 2.998 & 0.657 & 1.364 & 3.463 & 0.009 & 0.855 & $a>c$ \\
\hline Country ${ }^{d}$ & 82 & 3.363 & 0.663 & & & & & \\
\hline Company e & 15 & 3.333 & 0.498 & & & & & \\
\hline \multicolumn{9}{|c|}{ Types of social support $(n=260)$} \\
\hline Mass media $\alpha^{2}$ & 63 & 3.454 & 0.654 & & & & & \\
\hline Analog media $\beta$ & 40 & 3.323 & 0.455 & & & & & \\
\hline $\begin{array}{c}\text { Social network } \\
\text { service } \gamma\end{array}$ & 52 & 3.365 & 0.662 & 0.156 & 0.380 & 0.768 & 0.124 & \\
\hline $\begin{array}{l}\text { Conversation and } \\
\text { encouragement } \delta\end{array}$ & 105 & 3.394 & 0.682 & & & & & \\
\hline
\end{tabular}

Note: ${ }^{a}$ Family, ${ }^{b}$ Friend, ${ }^{c}$ Colleague, ${ }^{d}$ Country, ${ }^{e}$ Company, ${ }^{\alpha}$ Mass media, ${ }^{\beta}$ Analog media, $\gamma$ Social network service, ${ }^{\delta}$ Conversation and encouragement. 
Table 4. Results of one-way analysis of variance about job retention intention.

\begin{tabular}{|c|c|c|c|c|c|c|c|c|}
\hline Item & $\begin{array}{l}\text { Frequency } \\
\qquad(n)\end{array}$ & Average & $\begin{array}{l}\text { Standard } \\
\text { Deviation }\end{array}$ & $\begin{array}{l}\text { Mean } \\
\text { Square }\end{array}$ & $\mathbf{F}$ & Probability & $\begin{array}{l}\text { Observed } \\
\text { Power }\end{array}$ & $\begin{array}{c}\text { Post } \\
\text { Verification }\end{array}$ \\
\hline \multicolumn{4}{|c|}{ Experience of social support $(n=377)$} & \multirow{3}{*}{1.531} & \multirow{3}{*}{1.519} & \multirow{3}{*}{0.219} & \multirow{3}{*}{0.233} & \\
\hline Yes & 260 & 3.814 & 1.009 & & & & & \\
\hline No & 117 & 3.952 & 1.001 & & & & & \\
\hline \multicolumn{4}{|c|}{ Social support categories $(n=260)$} & \multirow{6}{*}{2.918} & \multirow{6}{*}{2.997} & \multirow{6}{*}{0.019} & \multirow{6}{*}{0.794} & \\
\hline Family $^{\mathrm{a}}$ & 93 & 4.017 & 0.904 & & & & & \\
\hline Friend ${ }^{b}$ & 50 & 3.713 & 1.130 & & & & & \\
\hline Colleague $^{\mathrm{c}}$ & 20 & 3.616 & 1.082 & & & & & \\
\hline Country ${ }^{d}$ & 82 & 4.174 & 0.968 & & & & & \\
\hline Company ${ }^{\mathrm{e}}$ & 15 & 3.577 & 0.929 & & & & & \\
\hline \multicolumn{4}{|c|}{ Types of social support $(n=260)$} & \multirow{5}{*}{3.311} & \multirow{5}{*}{3.389} & \multirow{5}{*}{0.019} & \multirow{5}{*}{0.762} & \multirow{5}{*}{$\alpha>\beta$} \\
\hline Mass media ${ }^{\alpha}$ & 63 & 4.227 & 0.972 & & & & & \\
\hline Analog media $\beta$ & 40 & 3.600 & 0.777 & & & & & \\
\hline $\begin{array}{l}\text { Social network } \\
\text { service } \gamma\end{array}$ & 52 & 3.891 & 0.930 & & & & & \\
\hline $\begin{array}{l}\text { Conversation and } \\
\text { encouragement } \delta\end{array}$ & 105 & 3.952 & 1.090 & & & & & \\
\hline
\end{tabular}

Note: ${ }^{a}$ Family, ${ }^{b}$ Friend, ${ }^{c}$ Colleague, ${ }^{\mathrm{d}}$ Country, ${ }^{\mathrm{e}}$ Company, ${ }^{\alpha}$ Mass media, ${ }^{\beta}$ Analog media, $\gamma$ Social network service, ${ }^{\delta}$ Conversation and encouragement.

\section{Discussion}

This study explored the job engagement and job retention intention of nurses who are nursing patients despite the risks in the long-term COVID-19 pandemic situation. There were differences in the nurses' job engagement and job retention intention depending on their social characteristics. A specific discussion of these findings follows.

First, the participants recorded higher job engagement and job retention intention depending on their age and work experience. The research findings support the results of previous research on the job engagement of nurses and organizational citizenship behavior, which revealed that a higher age leads to increased job engagement, organizational citizenship behavior, and career involvement [36]. Organizational citizenship behavior contributes to the maintenance and reinforcement of social and psychological contexts that support task performance for organizations above a minimum demand for duties, and it is necessary for medical treatment jobs. Medical organizations require close communication and cooperation between employees, and flexible job performance skills. This competence is complementary to "job engagement" with regard to carrying out duties with a positive attitude $[37,38]$. Nursing duties generally involve working in teams across three shifts to carry out continuous nursing duties. Therefore, in such a difficult situation as a pandemic, team formation that includes a nurse who is older and more experienced could help heighten nurses' job engagement and job retention intention.

For COVID-19-related factors, job retention intention was low for the group who had experience taking care of patients infected with COVID-19 and the nurses working in COVID-19-related divisions. This result is similar to that of previous research, which has shown that exposure to environmental risks negatively influences the choice of sustainable jobs [39]. Before nurses in South Korea select their jobs, they take the oath of the Nightingale Pledge. This is because health and medical care are difficult and require sacrifices [40]. However, the study result implies that nurses' work ethic as professionals could diminish in situations similar to the COVID-19 pandemic in which their own lives are at risk. The decrease in the job retention intention of nurses signifies the decline of the nursing workforce, which is a large barrier to overcoming the COVID-19 situation. Accordingly, it has been suggested that measures are needed to heighten the job retention intention of nurses who work in COVID-19-related divisions, or care for patients infected with COVID-19. In particular, it should be taken into account that working in a stressful working environment (e.g., emergency department) or organizational variables (e.g., bad working environment) may lead to a low intention to retain the job.

Lastly, there are differences in job engagement and job retention intention based on the categories and types of social support. This result is consistent with the research results that state that social 
support reduces job stress [41] and helps overcome disasters [42]. In addition, research targeted at nurses reports that the level of burnout decreases as social support increases [43]. Even in this study, the group that received support from their family in the same context showed the highest job engagement and job retention intention. Currently, nurses are struggling psychologically with the exposure of their families to potential COVID-19 infection [44]. Therefore, family support could have increased importance for them because family members' support can reduce concerns about infecting family members because of their work. Regarding types of social support, support through mass media showed high job engagement and job retention intention. The mass media applies the most direct decisive measures to people and society [45]. It has been reported that providing information about individuals in mass media positively influences their self-esteem, image, and sense of belonging [46]. The research finding of this study has the same context, as it suggests that the group that recognizes social support through mass media has high job engagement and job retention intention. As the world continues to battle the pandemic, we need to support nurses who are treating COVID-19 patients with continuous messages of encouragement through the media.

This study identified the differences in nurses' job engagement and job retention intention through their social characteristics and social support to ensure the necessary job retention to cope with the COVID-19 situation. Nevertheless, this study has the following limitations: First, the continuing COVID-19 situation could cause varied job retention intentions depending on the level of fatigue and risks felt by nurses, so careful consideration is required in interpretation. Second, social support could vary according to method and meanings, depending on individuals' cultural differences. Third, this study was conducted in the context of COVID-19, a global infectious disease. Therefore, it is necessary to take care when extending interpretations to ordinary situations. Fourth, this study was conducted as a basic study due to the special circumstances of COVID-19. In future studies, a study including a control group should be conducted to increase the effectiveness. Lastly, this study identifies differences as a cross-sectional study, so it does not represent causal relations.

\section{Conclusions}

This study shows that the differences in job engagement and job retention intention of nurses working on the frontlines of the COVID-19 situation depend on their social characteristics and support. Differences in job engagement and job retention intention are based on nurses' individual characteristics and working environments, so these characteristics must be considered in operations for nurses to continue in their jobs. In particular, the job retention intention of nurses working in COVID-19-related divisions was low; this issue should be taken into careful consideration. Low job retention intention could cause significant damage to the nursing workforce, and it should be recognized that this may cause hardships in overcoming the COVID-19 pandemic. To win against COVID-19 and adequately prepare for a future COVID-19 pandemic situation, press media targeting nurses (e.g., news, articles, and documentaries) should become more active and family support should be provided.

Author Contributions: Conceptualization, Y.-J.K. and S.-Y.L.; Methodology, J.-H.C.; Validation, Y.-J.K., S.-Y.L. and J.-H.C.; Formal Analysis, J.-H.C.; Investigation, S.-Y.L. and J.-H.C.; Data Curation, J.-H.C. and Y.-J.K.; Writing-Original Draft Preparation, S.-Y.L.; Writing-Review and Editing, S.-Y.L. and Y.-J.K. All authors have read and agreed to the published version of the manuscript.

Funding: This research received no external funding.

Conflicts of Interest: The authors declare no conflict of interest.

\section{References}

1. Cirrincione, L.; Plescia, F.; Ledda, C.; Rapisarda, V.; Martorana, D.; Moldovan, R.E.; Theodoridou, K.; Cannizzaro, E. COVID-19 Pandemic: Prevention and protection measures to be adopted at the workplace. Sustainability 2020, 12, 3603. [CrossRef]

2. Worldometer. Coronavirus Cases. COVID-19 Coronavirus Pandemic. Available online: https://www. worldometers.info/ (accessed on 7 May 2020). 
3. Kim, Y.J.; Cho, J.H. Correlation between preventive health behaviors and psycho-social health based on the leisure activities of South Koreans in the COVID-19 crisis. Int. J. Environ. Res. Public Health 2020, 17, 4066. [CrossRef]

4. Kutikov, A.; Weinberg, D.S.; Edelman, M.J.; Horwitz, E.M.; Uzzo, R.G.; Fisher, R.I. A war on two fronts: Cancer care in the time of COVID-19. Ann. Intern. Med. 2020, 172, 756-758. [CrossRef] [PubMed]

5. Pirouz, B.; Haghshenas, S.; Haghshenas, S.S.; Piro, P. Investigating a serious challenge in the sustainable development process: Analysis of confirmed cases of COVID-19 (new type of coronavirus) through a binary classification using artificial intelligence and regression analysis. Sustainability 2020, 12, 2427. [CrossRef]

6. Cohen, J.; Kupferschmidt, K. Countries test tactics in 'war' against COVID-19. Science 2020, 367, 1287-1288. [CrossRef]

7. Huang, L.; Lin, G.; Tang, L.; Yu, L.; Zhou, Z. Special attention to nurses' protection during the Covid-19 epidemic. Crit. Care 2020, 24. [CrossRef] [PubMed]

8. Hewings-Martin, Y. 'It's Really a Hard Time Right Now, Says Chicago Nurse Looking after COVID-19 Patients. Medical News Today. Available online: https://www.medicalnewstoday.com/articles/its-really-ahard-time-right-now-says-chicago-nurse-looking-after-covid-19-patients (accessed on 28 April 2020).

9. Nowell, A. Hospice Nurse Describes how Covid-19 Has Changed her Work. Wigan Today. Available online: https://www.wigantoday.net/health/hospice-nurse-describes-how-covid-19-has-changed-her-work2886454 (accessed on 20 June 2020).

10. Sukheja, B. Good News: Five Heartwarming Stories to Cheer the Mood Amid COVID-19 Crisis. R. Republic World. Available online: https://www.republicworld.com/entertainment-news/whats-viral/fiveheartwarming-stories-to-cheer-up-amid-covid-19-lockdown.html (accessed on 7 May 2020).

11. Jones, L.A. Dancing Philly Nurses 'Level Up' Video Goes Viral, Garners Heartfelt Thanks from Celebs. Billy Penn. Available online: https://billypenn.com/2020/04/07/dancing-philly-nurses-level-up-video-goesviral-garners-heartfelt-thanks-from-celebs/ (accessed on 7 April 2020).

12. Juan, G.S.; Sara, D.S.; Macarena, R.M.; Mónica, O.M.; Juan, J.G.I.; Carlos, R.F. Sense of coherence and psychological distress among healthcare workers during the COVID-19 pandemic in Spain. Sustainability 2020, 12, 6855. [CrossRef]

13. Shirey, M.R. Social support in the workplace: Nurse leader implications. Nurs. Econ. 2004, 22, 313.

14. Nichole, E.; Kevin, B.W. Social network sites as vehicles for effective/ineffective social support. In Social Support and Health in the Digital Age; Lexington Books: Rowman \& Littlefield: Lanham, MD, USA, 2019.

15. Lee, A.S.; Yoon, C.K. Influence of ego-resilience and social support on the depression of hospital nurses. Korean J. Occup. Health Nurs. 2012, 21, 46-54. [CrossRef]

16. Kim, I.S. The role of self-efficacy and social support in the relationship between emotional labor and burn out, turn over intention among hospital nurses. J. Nurs. Adm. 2009, 15, 515-526.

17. Langford, C.P.H.; Bowsher, J.; Maloney, J.P.; Lillis, P.P. Social support: A conceptual analysis. J. Adv. Nurs. 1997, 25, 95-100. [CrossRef] [PubMed]

18. Sullivan, H.S. The Interpersonal Theory of Psychiatry; Perry, H.S., Gawel, M.L., Eds.; Norton: New York, NY, USA, 1953.

19. Krause, N. Chronic financial strain, social support, and depressive symptoms among older adults. Psychol. Aging 1987, 2, 185. [CrossRef] [PubMed]

20. Hagihara, A.; Tarumi, K.; Nobutomo, K. Positive and negative effects of social support on the relationship between work stress and alcohol consumption. J. Stud. Alcohol 2003, 64, 874-883. [CrossRef] [PubMed]

21. Jenkins, R.; Elliott, P. Stressors, burnout and social support: Nurses in acute mental health settings. J. Adv. Nurs. 2004, 48, 622-631. [CrossRef]

22. Laschinger, H.K.S.; Havens, D.S. The effect of workplace empowerment on staff nurses' occupational mental health and work effectiveness. J. Nurs. Adm. 1997, 27, 42-50. [CrossRef]

23. Laschinger, H.K.S.; Finegan, J.; Shamian, J.; Wilk, P. Workplace empowerment as a predictor of nurse burnout in restructured healthcare settings. Longwoods Rev. 2003, 1, 2-11.

24. Munro, L.; Rodwell, J.; Harding, L. Assessing occupational stress in psychiatric nurses using the full job strain model: The value of social support to nurses. Int. J. Nurs. 1998, 35, 339-345. [CrossRef]

25. Kim, H.; Stoner, M. Burnout and turnover intention among social workers: Effects of role stress, job autonomy and social support. Adm. Soc. Work 2008, 32, 5-25. [CrossRef] 
26. Jackson, D.; Bradbury-Jones, C.; Baptiste, D.; Gelling, L.; Morin, K.; Neville, S.; Smith, G.D. Life in the Pandemic: Some reflections on nursing in the context of COVID-19. J. Clin. Nurs. 2020, 29, 2041-4043. [CrossRef]

27. Liu, Z.; Han, B.; Jiang, R.; Huang, Y.; Ma, C.; Wen, J.; Ma, Y. Mental health status of doctors and nurses during COVID-19 epidemic in China. SSRN 2020. [CrossRef]

28. Wu, Y.; Wang, J.; Luo, C.; Hu, S.; Lin, X.; Anderson, A.E.; Qian, Y. A comparison of burnout frequency among oncology physicians and nurses working on the front lines and usual wards during the COVID-19 epidemic in Wuhan, China. J. Pain Symptom Manag. 2020, 60, 60-65. [CrossRef] [PubMed]

29. Maben, J.; Bridges, J. Covid-19: Supporting nurses' psychological and mental health. J. Clin. Nurs. 2020, 29, 2742-2750. [CrossRef] [PubMed]

30. Chang, C.S.; Du, P.L.; Huang, I.C. Nurses' perceptions of severe acute respiratory syndrome: Relationship between commitment and intention to leave nursing. J. Adv. Nurs. 2006, 54, 171-179. [CrossRef]

31. Maunder, R.; Hunter, J.; Vincent, L.; Bennett, J.; Peladeau, N.; Leszcz, M.; Sadavoy, J.; Verhaeghe, R.; Steinberg, L.M.; Mazzulli, T. The immediate psychological and occupational impact of the 2003 SARS outbreak in an teaching hospital. Can. Med. Assoc. J. 2003, 168, 1245-1251.

32. Kim, W.H.; Park, J.G.; Kwon, B. Work engagement in South Korea: Validation of the Korean version 9-item Utrecht work engagement scale. Psychol. Rep. 2017, 120, 561-578. [CrossRef]

33. Schaufeli, W.B.; Bakker, A.B.; Salanova, M. The measurement of work engagement with a short questionnaire: A cross-national study. Educ. Psychol. Meas. 2006, 66, 701-716. [CrossRef]

34. Ajzen, I. From intentions to actions: A theory of planned behavior. In Action-Control: From Cognition to Behavior; Springer: New York, NY, USA, 1985. [CrossRef]

35. Choo, E.H.; Baek, Y.M. Who supports MeToo movement, and how are they mobilized? Focusing on the different media mobilization mechanism between women and men. Korean Soc. J. Commun. Stud. 2018, 62, 37-65.

36. Song, E.J.; Kim, M.J.; Koh, M.S. Moderating effects of career commitment in the relationship between work engagement and organizational citizenship behaviors of the clinical nurses. J. Korean Acad. Nurs. Adm. 2019, 25, 167-174. [CrossRef]

37. Chae, M.O. Ego resilience, career decision-making self-efficacy and job seeking stress of senior nursing students. J. Digit. Converg. 2019, 17, 229-238. [CrossRef]

38. Kim, H.S.; Park, S.Y. The relationship between social network and organizational commitment and job satisfaction: Focused on mediating effects of job engagement. Soc. Sci. Stud. 2011, 35, 203-231.

39. Middermann, L.H.; Kratzer, J.; Perner, S. The impact of environmental risk exposure on the determinants of sustainable entrepreneurship. Sustainability 2020, 12, 1534. [CrossRef]

40. Luo, E. Increasing cost efficiency in health care without sacrificing the human touch. AMA J. Ethics 2015, 17, 1059-1063. [CrossRef] [PubMed]

41. La Rocco, J.M.; Jones, A.P. Organizational conditions affecting withdrawal intentions and decisions as moderated by work experience. Psychol. Rep. 1980, 46 (Suppl. S3), 1223-1231. [CrossRef]

42. Wilkin, J.; Biggs, E.; Tatem, A.J. Measurement of social networks for innovation within community disaster resilience. Sustainability 2019, 11, 1943. [CrossRef]

43. Yom, Y.H.; Kim, H.J. Effects of compassion satisfaction and social support in the relationship between compassion fatigue and burnout in hospital nurses. J. Korean Acad. Nurs. 2012, 42, 870-878. [CrossRef] [PubMed]

44. Sun, N.; Wei, L.; Shi, S.; Jiao, D.; Song, R.; Ma, L.; Liu, S. A qualitative study on the psychological experience of caregivers of COVID-19 patients. Am. J. Infect. Control 2020, 48, 592-598. [CrossRef] [PubMed]

45. Ball-Rokeach, S.J.; DeFleur, M.L. A dependency model of mass-media effects. Commun. Res. 1976, 3, 3-21. [CrossRef]

46. Rui, J.R.; Stefanone, M.A. Strategic image management online: Self-presentation, self-esteem and social network perspectives. Inf. Commun. Soc. 2013, 16, 1286-1305. [CrossRef]

(C) 2020 by the authors. Licensee MDPI, Basel, Switzerland. This article is an open access article distributed under the terms and conditions of the Creative Commons Attribution (CC BY) license (http://creativecommons.org/licenses/by/4.0/). 